\title{
História em quadrinhos e a função poética na publicidade
}

\section{Comics and the poetic function in advertising}

Roberto Elísio dos Santos ${ }^{1}$

Daniela Urbinati ${ }^{2}$

Iêda Lima dos Santos ${ }^{3}$

Resumo A relação entre a publicidade e as histórias em quadrinhos remonta ao início do século XX, quando as tiras publicadas em jornais atraíam a atenção crescente dos leitores. Partindo da função poética da linguagem, conforme a classificação feita pelo linguista russo Roman Jakobson, e seu uso na publicidade, este texto pretende categorizar as principais formas em que os quadrinhos atendem às necessidades de campanhas publicitárias. Por meio de elementos característicos da função poética da linguagem, os anúncios podem trazer informações úteis e manter-se interessantes e vendáveis.

Palavras-chave: Histórias em quadrinhos; Publicidade; Função poética da linguagem

Abstract The relation between advertising and comics goes back to the early 20 th century, when comic strips published in newspapers got the attention of a growing number of readers. Following the poetic function of the language, according to the Russian linguist Roman Jakobson, and its use in advertising, this paper intends to categorize the main forms in which comics serve to the needs of publicity campaigns. Through the characteristic elements of the poetic function of the language, advertising can bring useful information and keep itself interesting and profitable.

Keywords: Comics; Advertising; Poetic function of language

\footnotetext{
${ }^{1}$ Universidade Municipal de São Caetano do Sul - USCS, São Caetano do Sul, SP, Brasil. E-mail: roberto.elisio@yahoo.com.br

${ }^{2}$ Universidade Municipal de São Caetano do Sul - USCS, São Caetano do Sul, SP, Brasil.

E-mail: daniurbinati@hotmail.com

${ }^{3}$ Universidade Municipal de São Caetano do Sul - USCS, São Caetano do Sul, SP, Brasil.

E-mail: iedalsantos@uol.com.br
} 


\section{Introdução}

A publicidade, da mesma forma que as histórias em quadrinhos, tem sido presença constante no cotidiano das pessoas. Sua onipresença faz dela parte da bagagem que formará o repertório do indivíduo que com ela tem contato, não necessariamente a sua capacidade cognitiva ou a seus valores, mas ao fato de povoar a memória e o imaginário. Nesse sentido, este texto seguirá a diferenciação feita por Sant’Anna (2007) entre publicidade e propaganda. ${ }^{4}$

Este trabalho parte do princípio de que a propaganda, quando aliada a elementos da função poética da linguagem, facilita a compreensão de determinados conteúdos através de recursos estéticos que acabam atuando como mediadores de conteúdo. Dessa forma, a publicidade, quando associada à história em quadrinhos, pode se tornar um sistema simbólico que serve não apenas para a venda de produtos, como para a disseminação e o questionamento de determinadas ideias. Trata-se de um estudo qualitativo de nível exploratório com emprego de técnicas de pesquisa documental e de análise de conteúdo de peças publicitárias, que, de alguma forma, se relacionam às histórias em quadrinhos. O material selecionado foi produzido em épocas diferentes para caracterizar a relação perene entre dois produtos culturais massivos: os quadrinhos e a publicidade.

Quando se fala em propaganda que possui conteúdo informacional, pensa-se em peças publicitárias que habilitam o receptor para a discussão, desde o hábito que se tenta instituir até o próprio produto como efetivação deste hábito. Isso sem colocar em risco a intenção de venda do anunciante. O ponto de partida para inserir informações nas peças é o conhecimento do repertório de determinado público por parte dos profissionais da publicidade.

Conta-se, também, com a publicidade para que traga o novo, o diferente. Anúncios que tragam informações e padrões semelhantes aos

\footnotetext{
${ }^{4}$ Para esse autor, a palavra publicidade diz respeito a tornar público, divulgar, e normalmente é associada à venda de produtos, enquanto propaganda refere-se a uma ideia a ser incutida na mente do público.
} 
de seus concorrentes são redundantes e desinteressantes, "um dos casos da inutilidade da comunicação: o da redundância total” (PIGNATARI, 1996, p. 52). Tais anúncios perdem sua utilidade, não sendo eficientes em surpreender e encantar o público.

É obviamente fundamental a utilização de recursos estéticos e inovadores para tornar a linguagem informacional compatível ao repertório do público e ao seu interesse. Informação excessiva pode assumir a forma de entropia ou ruído, que perturba a recepção fiel da mensagem e impossibilita, assim, a decodificação desta. De acordo com Epstein:

(...) a informação ou a variedade máxima de um conjunto de eventos (ou de sinais) ocorre quando eles são independentes entre si, ou seja, não apresentam articulação ou coerção mútua (a desordem ou a entropia do conjunto, neste caso, é máxima) e este é o estado máximo de informação de onde não emerge nenhuma forma ou Gestalt (EPSTEIN, 1986, p. 6).

Para que haja compreensão, para que o receptor seja capaz de "traduzir" a mensagem, ou seja, para que o público crie uma significação para ela, ele necessita de forma, de algo passível de reconhecimento, para que o novo conteúdo passe de ininteligibilidade para inteligibilidade. A partir do momento em que a propaganda coloca o produto em segundo plano e trabalha o conteúdo que possa ser considerado relevante e enriqueça, efetivamente, o repertório do receptor, pode-se afirmar que o conceito de informação como aqui se apresenta se configura neste material de comunicação.

\section{A função poética da linguagem}

A compreensão da função poética da linguagem é, também, indispensável para a compreensão da proposta deste artigo. Dentre as funções da linguagem de Jakobson, a saber: referencial, fática, metalinguística, emotiva, conativa e poética, esta pesquisa considera a poética como sendo a mais eficiente para trabalhar conteúdos, complexos ou não, e aproximá-los do público, tornando-os mais fáceis de compreender. Dentre os seis elementos destacados por este mesmo autor dentro do 
processo de comunicação - emissor, receptor, código, canal, referente e mensagem -, um deles sempre se destaca no processo de comunicação e é este quem determina a função de linguagem predominante. Se o elemento predominante é o referente, a função predominante será a referencial; se o receptor, função conativa; emissor, função emotiva; o código, função metalinguística; o canal, função fática. Quando o destaque recai sobre a mensagem, sobre a forma como o conteúdo será transmitido, predomina a função poética da linguagem.

Sobre a função poética da linguagem de Jakobson (1969), Bigal (1999, p. 43) considera que a "função poética ou estética da linguagem tem como referente a própria mensagem, o que compõe sua ambivalência operacional. A mensagem volta-se para si mesma, para sua própria estrutura, para sua própria produção de sentidos".

Em um mesmo contexto, duas ou mais funções podem ocorrer simultaneamente: um poema em que o autor discorra sobre o que ele sente ao escrever poesia tem as linguagens poética, emotiva e metalinguística ao mesmo tempo:

Partindo-se do princípio de que a qualidade da mensagem é determinada pelo modo como se associam os fatores constitutivos do ato de comunicação e que, nessas associações, eles aparecem em diferentes ordens hierárquicas com a predominância de apenas um, conforme a associação, a estrutura verbal ou o perfil da mensagem dependerá da função predominante (BIGAL, 1999, p. 42).

As peças publicitárias analisadas possuem uma composição poético-estética publicitária, que, segundo Bigal (1999, p. 17), “ampliará a qualidade informacional dos repertórios médios da sociedade”. O objetivo é verificar o quanto tais peças podem contribuir com o repertório, tornando palatáveis suas informações com a utilização da função poética da linguagem. A “composição poético-estética” ocorrerá quando o efeito estético proporcionado pela peça publicitária tornar a mensagem seu ponto mais importante, ou seja, os elementos que compõem esta peça configuram-na de tal forma que a função de linguagem predominante seja a função poética. 
Para Epstein (1986, p. 45), com base nos estudos de Jakobson (1969), “a função poética coloca o centro de gravidade na própria configuração da mensagem correspondente aproximadamente à função estética dos signos". Para que predomine numa mensagem, a função poética da linguagem lança mão de todo e qualquer elemento que dê a seu conteúdo uma forma esteticamente agradável, dando destaque, mais do que para "o que" se diz, ao "como" se diz. Rimas, figuras de linguagem, neologismos, ritmo, grafismos, espacialidade e outras formas de estetizar o conteúdo são recursos utilizados pela função poética da linguagem. Todos eles considerados, aqui, capazes de tornar o conteúdo da mensagem mais atraente e passível de compreensão.

A função poética da linguagem, quando predomina no processo de comunicação, quebra paradigmas inclusive da organização e até da funcionalidade dos signos, aproximando-o do objeto pela sua estética. Essa é a capacidade de a linguagem tornar-se mais eficiente, na sua função de inserir novos dados no repertório de determinado público.

A linguagem poética, de forma geral, está fortemente presente no discurso publicitário. O anúncio publicitário pode se tornar memorável por uma série de fatores que o tornam uma peça democrática, na qual coexistem elementos de arte, mercadorias, atualidades, vestígios diversos do cotidiano e do imaginário dos receptores. A utilização da linguagem poética e a predominância da função poética da linguagem tornam esse diálogo mais agradável para o receptor.

Além disso, a composição poético-estética publicitária aumenta a "durabilidade" do anúncio: ao causar no receptor o prazer estético, servirá como base para reflexão e, portanto, poder-se-á recorrer a ele sempre. Tal característica do anúncio permite ao receptor explorá-lo diversas vezes, descobrindo em cada uma delas uma nova informação que se dará por uma nova interpretação.

Max Bense - filósofo, físico e matemático que preconizou uma "estética científica" com o objetivo de eliminar o juízo valorativo e interpretativo da estética tradicional -, em sua "teoria do repertório", diz que "o repertório do qual são gerados estados estéticos, ou seja, objetos 
artísticos, pode naturalmente ser concebido como ilimitado. Só repertórios finitos são manipuláveis, e portanto seletíveis" (apud BIGAL, 1999, p. 22).

Entende-se por repertório a diversidade de assuntos que uma pessoa apresenta e adquire para o desenvolvimento intelectual. Ao elaborar uma peça publicitária, é necessária uma pesquisa sobre o repertório e costumes do público-alvo para poder selecionar os elementos - no interior de seu repertório - que comporão essa peça. A associação desses elementos será retirada da sintaxe de outras linguagens como novelas, filmes, teatro, e tantas outras fontes, constituindo a sintaxe da publicidade. A sintaxe da publicidade não é fixa nem preestabelecida.

O estímulo do receptor com o uso de elementos passíveis de reconhecimento, mas informativos, estimula a emoção e o interesse, a busca por interagir com a peça. Para Gibson (1986, p. 242), "as qualidades dos objetos são especificadas pelas informações; as qualidades dos receptores e nervos são especificadas pelas sensações. As informações sobre o mundo afetam as qualidades do sentido. Ainda nesse sentido, Pignatari (2004, p. 18) sentencia que: "Um poema transmite a qualidade de um sentimento. Mesmo quando parece estar veiculando ideias, ele está é transmitindo a qualidade do sentimento dessa ideia. Uma ideia para ser sentida e não apenas entendida, explicada, descascada”. E acrescenta: "A maioria das pessoas lê poesia como se fosse prosa. A maioria quer “conteúdos” - mas não percebe formas. Em arte, forma e conteúdo não podem ser separados".

\section{História em quadrinhos e publicidade}

Dentro do espectro da função poética da linguagem na publicidade, a história em quadrinhos fornece elementos verbais e plástico-visuais às peças e campanhas. Arte sequencial, como define Eisner (1989, p. 5), é "um veículo de expressão criativa, uma disciplina distinta, uma forma artística e literária que lida com a disposição de figuras ou imagens e palavras para narrar uma história ou dramatizar uma ideia”. Os quadrinhos conjugam, portanto, a arte da escrita (roteiro), do desenho, do 
letreiramento e da colorização. O estilo gráfico dos artistas - a maneira como eles retratam pessoas, cenários e objetos, usando traços e técnicas variados - compõe o arcabouço estético e, muitas vezes, metafórico que os quadrinhos emprestam aos anúncios publicitários.

É possível categorizar essa relação entre quadrinhos e publicidade a partir das formas como esses produtos intercambiam suas linguagens e discursos:

- Peças e campanhas que se valem da figura de um personagem conhecido pelo público para emprestar "sua fama" ao produto ou à marca;

- Os personagens tornam-se eles próprios artigos de consumo ou emprestam seus nomes a produtos;

- Personagens de destaque que participam de campanhas institucionais;

- Peças ou campanhas que adotam elementos da linguagem dos quadrinhos;

- Anúncios que assumem o formato e a narrativa dos quadrinhos;

- Histórias em quadrinhos completas, às vezes ocupando uma publicação inteira, que servem para vender um produto ou uma ideia.

O primeiro caso é quase um "testemunhal”, em que o personagem dá sua garantia sobre a qualidade do produto. Gordon (1998, p. 3) afirma que os pesquisadores localizam a emergência, nos Estados Unidos, de uma cultura de consumo de massa nas duas últimas décadas do século XIX e no início do século seguinte, devido a "questões econômicas, tecnológicas, especialmente as de transporte e de comunicação, à produção em larga escala, à disseminação da publicidade em escala nacional e uma nova cultura do lazer".

Para Kotler (2000, p. 103), "muitas alianças estratégicas tomam a forma de" alianças de marketing. Esse teórico identifica quatro categorias principais, entre elas as alianças promocionais, nas quais "uma empresa concorda em promover um produto ou serviço de outra”. A cadeia de fast-food McDonald's, por exemplo, associou-se à Walt Disney 
Company para oferecer bonecos da personagem Mulan a quem comprasse seus sanduíches.

De acordo com Gordon (1998, p. 37), o travesso Buster Brown (chamado de Chiquinho no Brasil), criado para as tiras de jornal em 1902 por Richard Felton Outcault, foi um dos primeiros personagens dos comics $^{5}$ estadunidenses a serem licenciados, ao lado de Sobrinhos do Capitão (elaborados por Rudolph Dirks) e Happy Hooligan (de Burr Opper), para publicação em outros jornais do país. Ao lado das tiras, que atingiam seu pleno potencial, o autor passou a licenciar o personagem para fabricantes de uma gama variada de produtos. Na Figura 1, por exemplo, o garoto e seu cachorro Tige (Jagunço) demonstram a resistência da meia que recebe o nome do personagem, em um anúncio publicado no início do século XX.

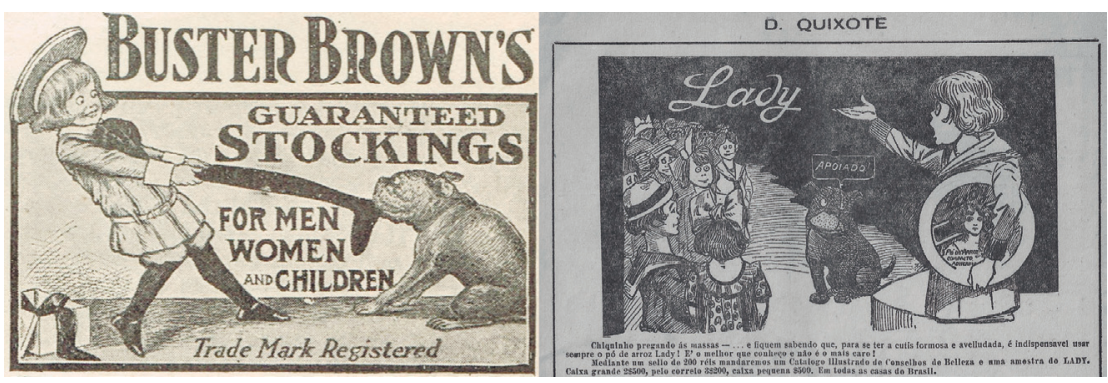

Figura 1: Peça publicitária impressa de meias protagonizada por Buster Brown (Chiquinho); no Brasil, o mesmo personagem aparecia em anúncios de diversos produtos, sem que seu criador soubesse.

Fontes: http://knickoftime.net/2014/08/antique-graphics-wednesday-buster-brown-advertisement.html e https://keyimaguirejunior.wordpress.com/2014/10/03/d-quixote-um-gibi-dos-velhos-tempos/. Acesso em: 10 ago. 2015.

\footnotetext{
${ }^{5}$ Nos Estados Unidos, as histórias em quadrinhos são chamadas comics devido ao fato de as primeiras tiras publicadas em jornais impressos, no final do século XIX, serem humorísticas. Depois, independentemente do gênero (terror, ficção científica, de heróis etc.), essa denominação foi mantida.
} 
Por conta de sua popularidade, contudo, esse personagem infantil já anunciou até cigarros "que o papai gosta" nas páginas da revista O Tico-Tico na década de 1930, da mesma forma que o simpático Joe Cammel, camelo antropomorfizado que usava óculos escuros, criado em 1974, aparecia nas peças do cigarro marca Cammel. O uso de personagens infantis em peças publicitárias tem gerado debate e novas normas, que procuram impedir que as crianças sejam expostas a estímulos que levem ao consumo de produtos ou serviços que ponham em risco a sua saúde (em particular, campanhas de bebidas alcoólicas ou de alimentos que levam à obesidade), sendo a resolução 163 da Conanda ${ }^{6}$ um exemplo, uma vez que considera abusiva "a prática do direcionamento de publicidade e de comunicação mercadológica à criança, com a intenção de persuadi-la para o consumo de qualquer produto ou serviço" que utilize, entre outros, "personagens ou apresentadores infantis, desenho animado ou de animação".

Cartunista e criador do jornal alternativo Ovelha Negra, Geandré (1996) denomina de marketing comics esses personagens da cultura do consumo empregados em produtos vendidos em supermercados, a exemplo dos alimentícios ou de higiene, limpeza e saúde. Para esse autor (1996, p. 25-26), existem dois tipos de personagens: "os vivos (pessoas, como atores e personalidades que personificam um determinado tipo) e os animados". Existe, também, a diferença entre os personagens licenciados, que pertencem a uma empresa (como a Disney, por exemplo), e os que são criados especificamente para as peças e campanhas publicitárias - Geandré considera esses como "personagens-logotipos" (1996, p. 17).

O quadrinista brasileiro que melhor soube aproveitar seus personagens é Mauricio de Sousa: desde meados da década de 1960, o artista soube produzir, distribuir e licenciar suas criações. Em desenhos animados feitos para a televisão, a Turma da Mônica anunciava os produtos da Cica, como marmelada, e principalmente o extrato de tomate Elefante,

\footnotetext{
${ }^{6}$ Secretaria de Direitos Humanos. Conselho Nacional dos Direitos da Criança e do Adolescente. Resolução n 163, de 13 de março de 2014.
} 
estrelado por Jotalhão (tendo como slogan "O elefante mais amado do Brasil”). Na década de 1970, com a publicação de revistas periódicas de histórias em quadrinhos - inicialmente pela Editora Abril, depois pela Globo e, no início do século XXI, pela Panini -, esses tipos se popularizaram e passaram a vender brinquedos, alimentos, produtos de higiene e limpeza e têxteis (roupas, peças de cama, mesa e banho), entre outros.
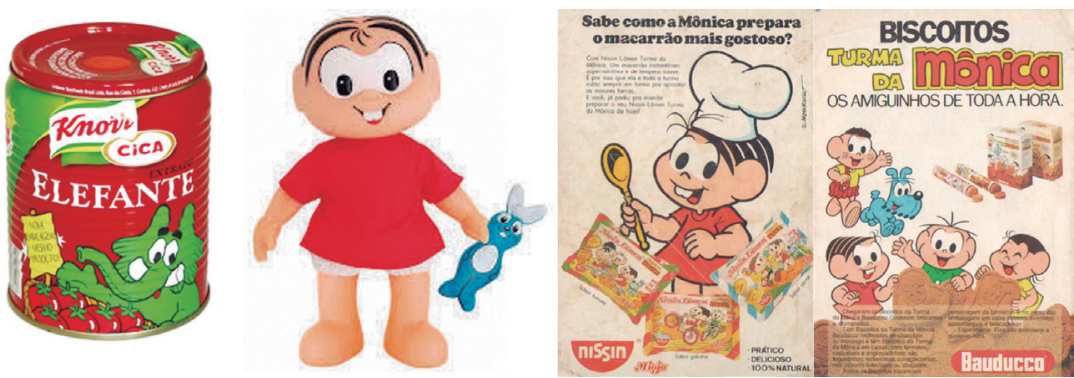

Figura 2: Extrato de tomate Elefante com desenho de Jotalhão, boneca da Mônica, também peça do macarrão Nissin e dos biscoitos Bauducco da Turma da Mônica.

Fonte: Acervo do autor

No entanto, ao emprestar sua imagem para divulgar determinados produtos ou serviços, os personagens podem sofrer alterações para se adequar às características da marca ou da campanha. É o caso do marinheiro Popeye, que extrai sua força da ingestão de espinafre, mas, em uma peça realizada no final dos anos 1980, come aveia Quaker para enfrentar e derrotar um alienígena. Outra campanha que causou indignação nos leitores de quadrinhos foi a da rede McDonald's com Asterix e seus amigos. Defensor da cultura francesa tradicional, a visão do guerreiro gaulês comendo a comida padronizada de uma marca de global de fast-food causa estranheza - normalmente, ao final de suas aventuras, ele compartilha suas façanhas com os membros de sua aldeia durante um banquete regado a javali assado e vinho. 


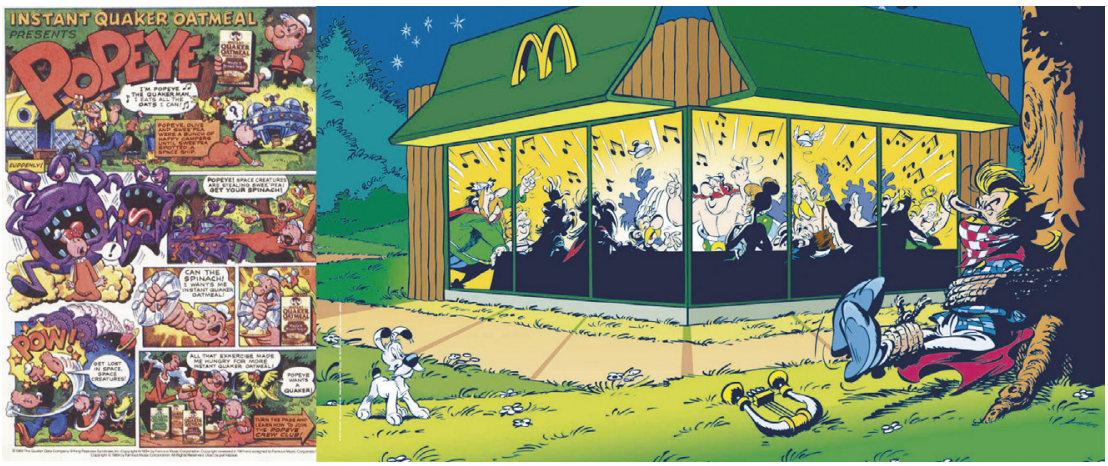

Figura 3: Popeye enfrenta extraterrestre comendo farinha de aveia e os conterrâneos do guerreiro gaulês Asterix frequentam um restaurante da rede estadunidense de fast-food McDonald's.

Fonte: Acervo do autor

As histórias e personagens de quadrinhos não são empregados apenas para vender e disseminar produtos de consumo. Considerem-se, por exemplo, as campanhas institucionais ou educativas, que tratam de questões ligadas ao meio ambiente ou são usadas para propagar conceitos de cidadania, relacionados à defesa do meio ambiente ou da inclusão social.

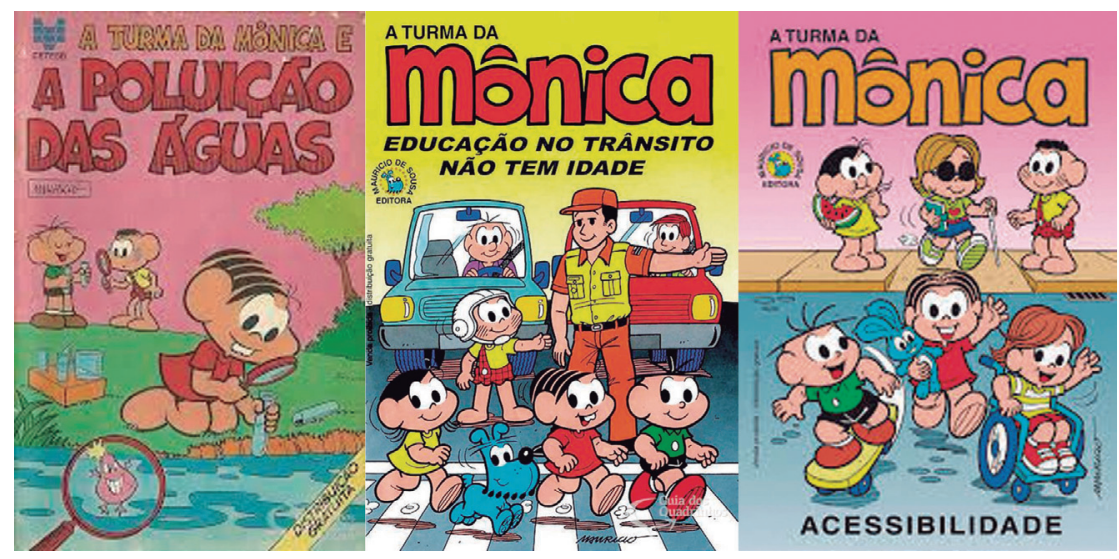

Figura 4: Revistas de quadrinhos institucionais produzidas por Mauricio de Sousa e distribuídas gratuitamente que abordam temas ecológicos, educativos e sociais.

Fonte: Acervo do autor 
Outro exemplo do emprego das histórias em quadrinhos para disseminar questões sociais emblemáticas ocorreu na década de 1980, quando a Aids se alastrava e havia dúvidas e muito preconceito em relação à doença. A editora estadunidense DC Comics realizou narrativas de uma página, estreladas pelos jovens super-heróis de suas revistas, para tratar do assunto. Essas pequenas histórias apareciam no miolo de seus principais títulos, como Liga da Justiça.
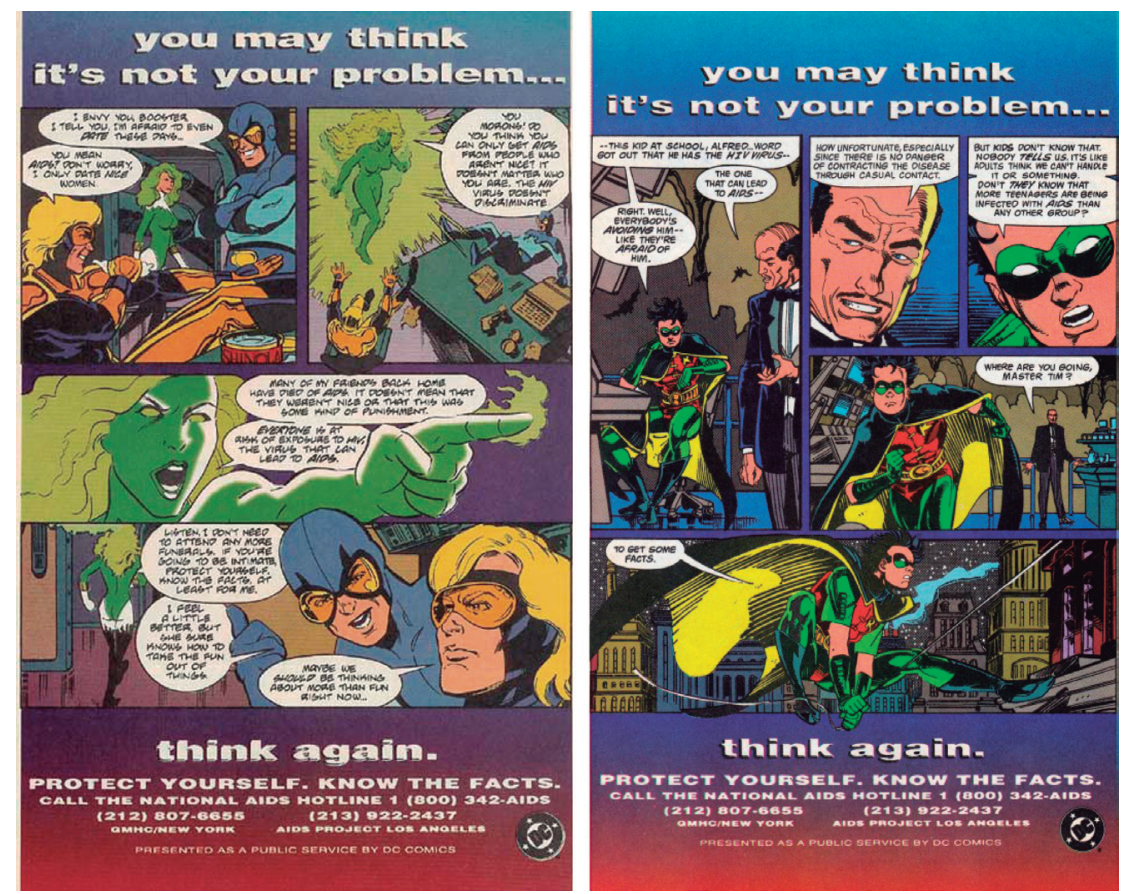

Figura 5: Propagandas educativas em forma de histórias em quadrinhos que tratam de temas ligados à Aids discutidos pelos heróis da DC Comics. Fonte: Acervo do autor

A linguagem das histórias em quadrinhos, por ser facilmente reconhecida pelo público, pode ser apropriada pela publicidade. Trata-se de um dos pontos máximos da função poética na relação entre quadrinhos e publicidade. Linhas cinéticas (riscos que indicam deslocamento 
espacial), balões de fala ou pensamento e onomatopeias (representação de sons, normalmente ruídos como explosões e impactos) são adotados em algumas peças e acabam fazendo parte da função poética da linguagem e identificados de pronto justamente por fazerem parte de um produto cultural popular.
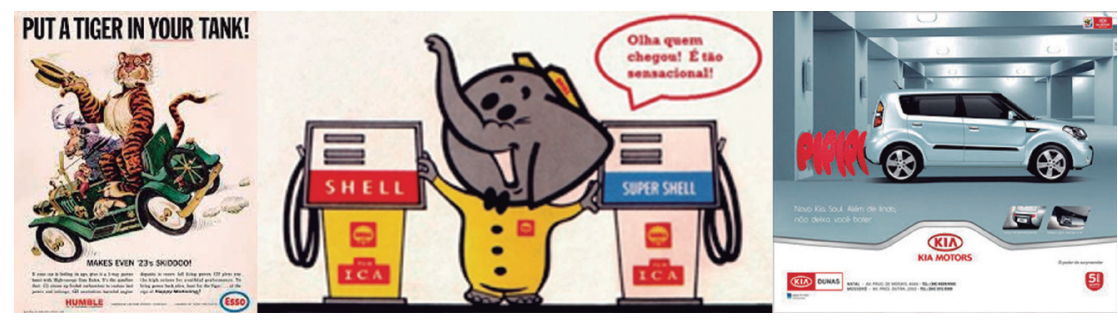

Figura 6: Peças que utilizam elementos da linguagem dos quadrinhos (metáforas visuais, linhas cinéticas, balões de fala e onomatopeias).

Fonte: https:/quietripple.wordpress.com/2013/06/11/put-a-tiger-in-your-tank/ (acesso em: 10 ago. 2015) e acervo do autor

Determinadas peças são apresentadas com a estrutura narrativa da história em quadrinhos, ou seja, a partir da relação sequencial que se estabelece entre imagens e textos. Campanhas publicitárias - como das empresas Esso, Shell e Kia Motors - exploram o uso de balões, onomatopeias e desenhos que ampliam o sentido poético e estético das peças. A Kia simboliza com a onomatopeia o barulho do bip de estacionamento, colocando de certa forma o som em sua imagem estática e "muda", fazendo com que esse som também seja uma imagem. A Shell possibilita que seu personagem-logotipo, o elefantinho frentista de posto de gasolina, fale com o público, enquanto a Esso faz ligação criativa entre seu título e a imagem principal (a do tigre, cujas características de força e velocidade são transferidas metaforicamente ao produto), enquanto o automóvel é mostrado em movimento acelerado pela metáfora visual da fumacinha e por linhas cinéticas. As três peças exemplificam uma quebra de padrões publicitários ao utilizar características dos quadrinhos em seu leiaute. 
O formato tradicional dos quadrinhos também pode ser uma possibilidade de apresentação gráfica de peças publicitárias. Porém, a relação publicidade-quadrinhos nem sempre é aceita pelos pesquisadores da Nona Arte. Srbek (2006), por exemplo, observa que,

apropriada pela publicidade, normalmente a linguagem dos quadrinhos compõe signos para otimismo espontaneísta, ausência de pensamento reflexivo e comunhão de pseudovalores. Enfim, o que é uma forma de arte acaba reduzido a clichê reprodutor de uma concepção de mundo idealizada segundo os padrões do consumo e do conformismo (SRBEK, 2006, p. 35).

Esse autor ressalta, de forma crítica, que a arte sequencial "acaba por servir como mais um elemento de homogeneização do ambiente urbano, que contribui para a ilusão de vivermos numa realidade harmônica". É preciso ressaltar, porém, que, da mesma forma que outros produtos culturais midiáticos (filmes, músicas, programas televisivos ou radiofônicos), a publicidade e os quadrinhos fazem parte da grande semiosfera que compõe o mundo contemporâneo e ajudam a formar o imaginário individual e coletivo.

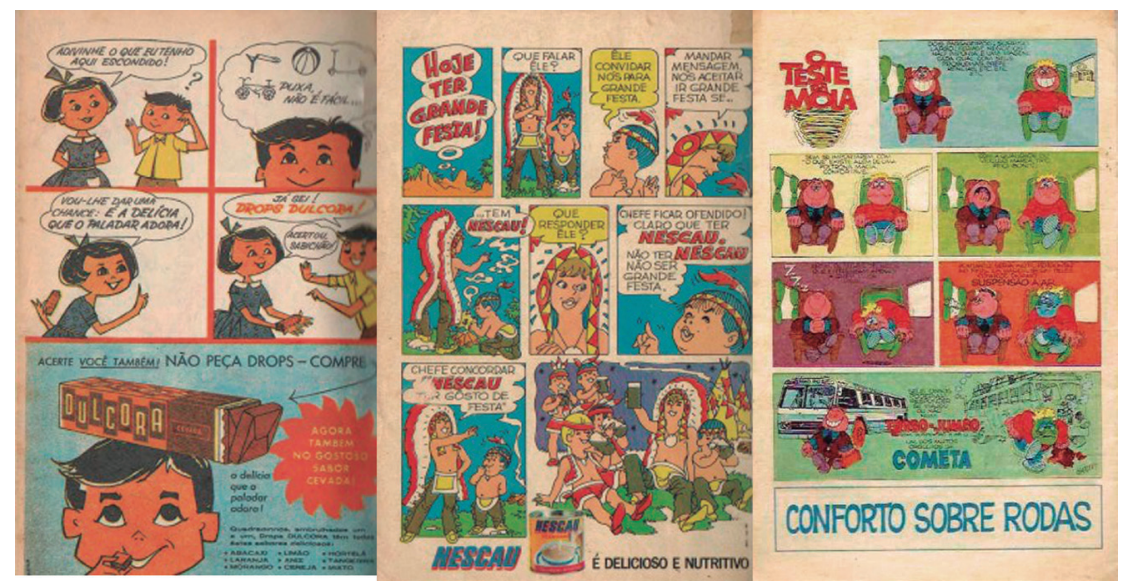

Figura 7: Peças publicitárias no formato de histórias em quadrinhos, que empregam a narrativa sequencial para apresentar os produtos.

Fonte: Acervo do autor 
O uso de quadrinhos, ou de sua linguagem, na publicidade pode enriquecê-la dos pontos de vista estético e criativo, como nas imagens apresentadas nos anúncios do drops Dulcora, do achocolatado Nescau e da Viação Cometa (Figura 7), que usam a arte sequencial com suas características gráficas perfeitamente, com balões de fala, desenhos e a divisão dos quadros em encapsulamento, ${ }^{7}$ mostrando que é possível contar uma história fazendo propaganda. O narrador conta uma história com imagens e textos dispostos de maneira sequencial, ao mesmo tempo em que é exibido o produto anunciado. $\mathrm{O}$ amálgama da relação publicidade-quadrinhos é o ponto que alcança o objetivo de "venda", sendo de fácil leitura. "Leiautes muito sofisticados ou uma técnica rebuscada demais, que podem subjugar e distrair o leitor e tomar conta da história, são contraproducentes neste formato", afirma Eisner (2013, p. 40).

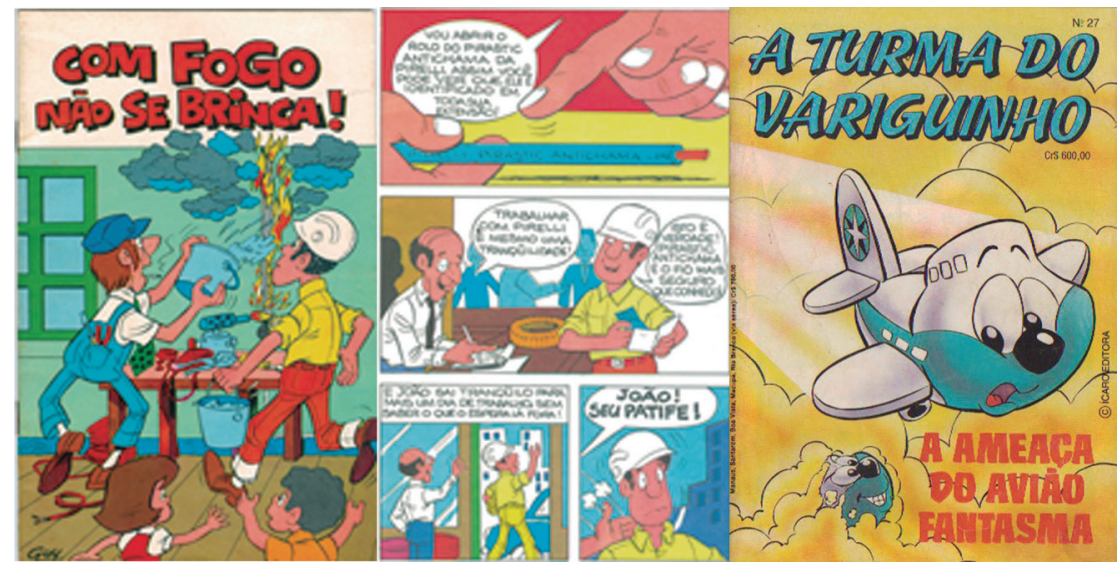

Figura 8: Campanha dos fios e cabos da Pirelli apresentados em uma longa narrativa; Variguinho ganha revista própria com histórias cômicas e de aventura protagonizadas pelo personagem-logotipo da Varig.

Fonte: Acervo do autor

\footnotetext{
7 Para Duncan e Smith (2009, p. 131), “o processo de encapsulamento [encapsulation] envolve a seleção de certos momentos da ação principal da história imaginada, encapsulando, ou delimitando, pedaços daqueles momentos em um espaço restrito (uma unidade dos quadrinhos que é chamada de vinheta, independentemente de existirem ou não as linhas do requadro)".
} 
A companhia aérea Varig criou o personagem-logotipo Variguinho, elaborado pelo publicitário Delcio Pereira. A empresa investiu no personagem, que inicialmente era apenas uma mascote, mas acabou tornando-se o protagonista de histórias em quadrinhos, ganhando título próprio e companheiros de aventura. Já a empresa de cabos elétricos Pirelli apresentou uma campanha para o fio Pirastic Antichamas em forma de gibi (revista de quadrinhos) para explicar o uso do produto e evidenciar todos os problemas que ele evitaria ao ser usado.

\section{Considerações finais}

As histórias em quadrinhos, como parte da função poética que pode ser utilizada pela publicidade, facilitam a compreensão da mensagem publicitária por parte do público. Cesar (2009, p. 39) constata que os quadrinhos (seja por causa de seus personagens famosos entre os leitores, de sua narrativa ou de sua linguagem), como os mencionados neste texto, juntam a importância da ideia e da forma para conquistar ou persuadir mais espectadores. "Quando se cria um anúncio, tudo precisa estar funcionando como uma engrenagem. Sem uma das partes, não vai funcionar. Pense sempre num todo. Texto precisa completar imagem; imagem precisa completar texto".

Assim, usando a criatividade, elemento-chave tanto da publicidade como dos quadrinhos, as peças usam as histórias em quadrinhos e sua linguagem para reforçar os conceitos da campanha, sem necessariamente empregar argumentos baseados na função referencial da linguagem, mas na fantasia gerada pela amplitude de sentidos gerada pela função poética, que captura a atenção do público a que se destina a campanha e acrescenta novas informações. Esses fatos evidenciam que o uso da narrativa quadrinhográfica pode ser um ponto alto da criatividade do publicitário, como aconselha o publicitário Roberto Menna Barreto: 
Se o caminho para tal (criatividade) passa pelo humor, vamos usar o humor, se passa pelo esclarecimento detalhado, vamos usar o esclarecimento detalhado; e assim por diante (BARRETO, 2004, p. 105).

Nos exemplos analisados, além dos elementos visuais-gráficos e estéticos das histórias em quadrinhos (estilo gráfico, cores etc.), a própria narrativa sequencial que emprega imagens e textos em continuidade serve como reforço argumentativo para a mensagem publicitária. Como essa narratividade é fragmentada em diversas vinhetas, o leitor pode preencher as lacunas e dar sentido ao conteúdo veiculado com sua imaginação.

\section{Referências}

BARRETO, R. M. Criatividade em propaganda. 12. ed. São Paulo: Summus, 2004.

BIGAL, S. O que é criação publicitária ou o estético na publicidade. 2. ed. São Paulo: Nobel, 1999.

CESAR, N. Direção de arte em propaganda. 9. ed. Brasília: Senac, 2009.

DUNCAN, R.; SMITH, M. J. The power of comics: an introduction to graphic storytelling. Nova York; Londres: Continuum Publishing, 2009.

EISNER, W. Narrativas Gráficas - princípios e práticas da lenda dos quadrinhos. 3. ed. São Paulo: Devir, 2013.

. Quadrinhos e arte sequencial. São Paulo: Martins Fontes, 1989.

EPSTEIN, I. Teoria da informação. 2. ed. São Paulo: Ática, 1986.

GEANDRÉ. Os marketing comics: uma guerra mercadológica no mundo publicitário. São Paulo: Global, 1996.

GIBSON, J. J. The ecological approach to visual perception. Nova Jersey: Lawrence Erlbaum Associates, 1986.

GORDON, I. Comic strips and consumer culture, 1890-1945. Washington; Londres: Smithsonian Institution Press, 1998.

JAKOBSON, Roman. Linguística e Comunicação. São Paulo: Cultrix, 1969.

KOTLER, P. Administração de marketing: a edição do novo milênio. São Paulo: Prentice Hall, 2000.

PIGNATARI, D. Informação, Linguagem e Comunicação. São Paulo: Cultrix, 1996. . O que é comunicação poética. 8. ed. São Paulo: Ateliê Editorial, 2004. 
106 HISTÓRIA EM QUADRINHOS E A FUNÇÃO POÉTICA NA PUBLICIDADE

SANT'ANNA, A. Propaganda: teoria - técnica - prática. 7. ed. São Paulo: Thomson Learning, 2007.

SECRETARIA DE DIREITOS HUMANOS. Conselho Nacional dos Direitos da Criança e do Adolescente. Resolução n. 163, de 13 de março de 2014. p. 1-2. Disponível em: http://www.mpba.mp.br/atuacao/infancia/publicidadeeconsumo/conanda/ resolucao_163_conanda.pdf. Acesso em: 22 jul. 2015.

SRBEK, W. Quadrinhos e outros bichos. João Pessoa: Marca de Fantasia, 2006.

Data de submissão: 28/04/2015

Data de aceite: 04/08/2015 